\title{
Chromaffin Granule Amine Transporter
}

National Cancer Institute

\section{Source}

National Cancer Institute. Chromaffin Granule Amine Transporter. NCI Thesaurus. Code C107580.

Chromaffin granule amine transporter (525 aa, $~ 56 \mathrm{kDa}$ ) is encoded by the human SLC18A1 gene. This protein is involved in the transport of biogenic monoamines into secretory vesicles. 